\title{
Re-Scaling the Socio-Ecological Italian Conflicts: Marginality as Arena of Practices
}

\author{
Alessandro Boldo1, Raffaella Freschi² \\ ${ }^{1}$ University of Ferrara, Ferrara, Italy \\ ${ }^{2}$ University IUAV in Venice, Venice, Italy \\ Email: bldlsn@unife.it, raffaella.freschi@libero.it
}

Received 1 October 2014; revised 10 November 2014; accepted 17 November 2014

Copyright (C) 2014 by authors and Scientific Research Publishing Inc.

This work is licensed under the Creative Commons Attribution International License (CC BY). http://creativecommons.org/licenses/by/4.0/

(c) (i) Open Access

\section{Abstract}

The progressive raising of socio-ecological conflicts in Italy and the ordinary abuse of "emergency regimes" are progressively contributing to the fragmentation of public sphere. In Italy, "territorial public action" has long since abandoned indeed the ability to arrange the goods according to the model of the Nation State and Welfare State: recent cases like ILVA in Taranto, the earthquake in L'Aquila, and the improper management of the "environmental regimes" testifying the growing of regional conflicts around distribution of bads and production of risks. Abusing of emergency regimes is becoming both a structural constraints and a strategy for Italian policies, forcing institutional rationality to set up umbrella concept-sustainable development for instance-, a body of international Law in its own right, but de facto proceed intentionally avoiding implementation processes, broadening space-temporal misfit, favoring negative cascade effects even on democracy spaces. Moreover, the vertical shift of political authority produces an enforcement of functional differentiations reducing the policy efforts for a multisectorial and multistakeholder approach, the occasions of citizenship and inclusion of public policies, enhancing on the opposite "territorial conflict" in collective resistance. The aim is not to test the validity of the best technique to solve territorial conflicts. Rather it is to show the right path of a counter-apparatus and the role of polycentric perspectives and micro-territorial practices enhancing cognitive processes on territorial policies and breaking up the organizational constraints of "emergentism". Using small case studies stands out the role of marginality as "creative approaches" that increase the governance (and government) effectiveness of public action, turning on the interstices that link different functional domains. Those capabilities are not usual to public action itself, belonging rather to community of practices. We name these "caring practices", able to foster opportunity to de-structuring consolidated bodies of knowledge and set an unusual interaction processes together with the institutions. These practices do not re-balance the conflicts, but are able to overturn territorial conflicts in a new "codex" of learning opportunities, helping to set up renewed political spaces widening the intensity of citizenship and generating territorial innovation. 


\section{Keywords}

\section{Socio-Ecological Conflicts, Alienation, Caring Practice}

\section{Preface, the Public Territorial Action: Symmetric Relation and Institutional Bond}

As a result of the recent and several socio-ecological conflicts Italian public action no longer plays the reference point in the national space policies. This research assumes that Nation-State action is no longer able to balance and ease the conflicts among disciplinary and constitutional fields according to the models of territorial distribution and re-distribution of goods.

Such model ruled the scene of the Nation-State and Welfare State model, and helped to establish a collective memory of a "Public action" involved in balancing the policies and in keeping under control the cascade effects on local communities. Yet, it is assumed that nowadays such model no longer provides the direct or indirect structural benefits inherited from the modernization cycles connected to the Fordism and Post-Fordism. Rather, the recurring succession of territorial conflicts appears to be the epiphenomenon of the alienation between the territories and the policies, with the formers competing in order to minimize the burden of bads and to share the related risks.

New narratives_such as the environment-are nowadays a novel field for the re-collocation of the political space [2] that lead to the spontaneous creation of arenas of practices [1] able to filter the aims of the large national and global agendas and to adapt them creatively to the micro-scale under a federative frame (à la Elazar).

Assuming the above mentioned considerations as our starting point and observing the main socio-ecological conflicts we are living, we are going to question the role of Public Action and started to valorise the contribution of the standing actors in engaging new storylines [3] and new political spaces helpful in the territorial innovation. Although the pluralization of drivers and of arenas of interactions in the conflicts can activate organizational learning processes, it does not ensure the steady effectiveness of the policies. The case we make focuses-on the other hand-on the caring of policy processes in order to ease the antagonism territories are involved in and to support territorial innovation structurally and strategically.

\section{The Autopoiesis of the Event}

\section{How does the Nation-State work?}

As the political-institutional energies come into action when socio-ecological emergencies occur, they are mainly employed in re-tuninig the instrumental gaps: such as reducing space-temporal misfit [4]-[6], avoiding cascade effects [7], questioning the implementation deficit or the lack of accountability. Nevertheless, public action is unawares willing to make up for such gaps by increasing the tools, the analysis, the "recipes", the models. If the gaps in the policies are considered chances to engage institutional innovations [8]-[10], the socio-ecological regimes [4] are nowadays highly dynamic systems with multilevel effects on the territories, that can hardy interact with factitious and synoptic frames.

As a matter of fact, neither the europeanisation processes, now well established in the ecological scenario, seems to have restored the traditional symmetric allocation of goods on the territories, nor they have reduced the gap between planning and implementation. On the contrary-enacting - their presence made available additional tools that have enlarged the spaces of mediation and extended waiting times giving few meaningful effects on the resilience of the socio-ecological systems.

It is scientifically recognized [11] that the institutional responses to socio-ecological emergencies nowadays need more adaptive strategies than in the past, with the result that very often they can't raise. Too often they are forced to respond resorting to the apparatus of "lex specialis derogat generali", a tool used to settle conflicts regardless of the causality and the motivation of the "specialis" Law. Indeed the specialis regulation engages where the territorial policies fail in terms of efficiency, in the gap and in the waiting time between policy making and implementation and it exploits the emergence to engage a panopticon system of social control.

Taranto 1 frame: the policies gaps as condition for the "state of emergency"

${ }^{1}$ An analogous case occurred at the Enel's plant in Porto Tolle (Rovigo)—North East of Italy-last 30 March: in this case the CEO Scaroni, and Enel president Tatò have been sentenced for environmental disaster. According to a technical survey of ISPRA-Institute for the Regional Health and Environmental Protection—socio-ecological damages are estimated tin 3.6 € billion: this survey has enable the Ministry of the Environment and the one of Health to enter into a civil lawsuit against the firm itself. 
Taranto-in Puglia, Southern Italy, is the centre of several high environmental impact industrial settlements: the Ilva, ENI refinery (with its storage of national strategic reserves), two power plants formerly owned by Edison and now property of Ilva, the Enipower plant, the Cementir (900,000 t annual production of concrete), two incinerators, one industrial dump (Italcave) the dumps of Ilva and one of the biggest and most important naval military base of the Mediterranean including the military arsenal to which add several small and medium sized companies [12]. The Ilva of Taranto is the the biggest steel plant in Europe, it covers a surface of 1500 hectares and employs 11,522 people-plus several satellite activities-; nevertheless due to the cumulative effects of the industrial activities Taranto is now one of the areas classified as cronically exposed to multi-sources pollution and one of the national areas where reclamations are needed (as stated by Law no. 426/98 and approved with D.M. 10/01/2000). A context in emergency worsened by the expert reports prepared by the attorney as regarding health (both of employees and citizens) and also by several studies and investigations, among which are "Sentieri” MISA and Epiair.

On July 26th, 2012 the Preliminary Investigations Judge, G. Todisco ordered the seizure and shut down of the hot working areas of Ilva ${ }^{2}$ following the results of the epidemiological survey. The confiscation and the shut down of the plants came in a moment of deep national economic crisis and extended the conflict beyond the social sphere and the struggle for power to constitutional issues, in particular for what concerns the right to health and to work ${ }^{3}$. The "government people" Monti and Letta committed to keep the production running: two lawdecrees named "save-Ilva", the arrangement of an External Emergency Plan and an ad hoc Integrated Environmental Authorization ${ }^{4}$ (A.I.A.) - with relevant guarantor"- the appointment of an inspector (former CEO of the company) and a committee of experts (see l'Aquila frame), nonetheless to stipulate with urgency, on July 26th 2012 a memorandum of understanding with the Region, local agencies and Port Authorities ${ }^{5}$. The memorandum of understanding was acknowledged by Law decree No. 171, 04/10/2012. Such Law classifies Taranto as an "area in complex industrial crisis", and the site a national's strategic area (only regarding economy) sphere.

Using the protocol by way of derogation is the tool to formalize the upswing industrial production guaranteeing a business plan for 2014 regarding industrial reconversion embedded in an urban and ecological adaption strategy.

In order to appeal to the "norma specialis", an additional dispositif is needed to allow Public action. That is the event, not necessarily accidental or physic one. As the case of Ilva suggests, although the norma specialis acknowledges the socio-ecological issues it settles them by setting up "closed-loop system" in which decision and policy making work —on purpose — to reduce the interacting variables and amplifying the mismatch between constitutional rights (Health and Work) ${ }^{6}$. The social and constitutional antagonism can’t be settled only within the sphere of the conflict itself, as they keep on feeding the conditions for the conflicts themselves to arise, where redundancy and bond interplay.

1) Redundancy. It's the starting point, the endemic fragility and morphological vulnerability ${ }^{7}$ of the Italian territory made worse by social effects and the heavy inheritance of the modernization cycles. According to reflexive modernization ${ }^{8}$ the evolution of social systems has exposed-often consciously-territories to critical conditions making them vulnerable to risks. What mostly affects social systems with multiple effects are induced damage as they establish structural connections between the vulnerability of territories, the increase of intensity of the phenomenons and the unpredictably of effects $[11]^{9}$.

\footnotetext{
${ }^{2}$ In supporting the seizure are the environmental and epidemiological maxi-surveys, that perform scientifically for the first time an evaluation on the effects of the plant emissions affecting the population of Taranto.

${ }^{3}$ Words of the President of “Associazione Nazionale Magistrati”, Rodolfo Sebelli in a public interview on 4 December 2012.

${ }^{4}$ L'A.I.A. (Environmental Integrated Authorisation) is a national measure—adopting the Directive. 2008/1/CE—certifying that the system is compliant with legal standards in compliance with D. Lgs 29 June 2010, n. 128. For Ilva, A.I.A. has been signed by the ex Environmental Ministry C. Clini on 26 October 2012.

5“The funds allocated amount to $€ 336.9$ million (329.7 $€$ million public and $7.2 €$ million private): 119 million $€$ allocated for soil recovery, 187 for harbour interventions, 30 for raising the local economy towards environmental sustainability. However, the total financial amount-composed mostly of items of expenditure already allocated but not yet paid-is not enough than the preset objectives and without total financial coverage. Moreover considering the fact that the share of the Puglia Region is locked by the Stability and Growth Pact" ([13] 67-68-self translation).

${ }^{6}$ The $41^{\text {st }}$ Article of Italian Constitution says that the economic initiative can’t be carry out in order to cause damage to the safety of people. ${ }^{7}$ The $82 \%$ of Italian territory is—-for instance-ranked as high hydrogeological risk.

${ }^{8}$ The reflexive contribution of inquiry involve authors as Schön, Beck, Giddens, Lash, Luhmann, Douglas, Donolo.

${ }^{9}$ The higher exposure the goods to the risks, the higher will be the frequencies with which events—even of low intensity—are able to produce significant damages. The so-called "localized damages" figures as negative externalities determined by the allocation of assets and human activities in risk-areas. For definition of cultural risk see Douglas e Wildavsky [14].
} 
2) The structural bonds. The event as a socio-political construct-rather than the efforts to work solutions out-is what mostly engages strategies of social domain. If the "norma specialis" matches legality and legitimacy, the occurring of the event has biopolitical consequences [15] not only on the wave of derogation or because it allows a commissioner to exercise extended powers, but as it stands on unconscious collective dynamics. Taking as examples the high-intensity socio-ecological conflicts we recently have experienced (whether it's and earthquake or the pollution exposure rates of Ilva) that the use of the event serves mostly as a political strategy on the national scenario ${ }^{10}$ almost a structural bond that politics relies on to affect social systems.

Nowadays, social systems have adapted to rely on both the cultural use of the risk [14] and that of the event, with the latter being in territorial managing policies, the only trigger to engage political actions. The interplay between the fragility of socio-ecological systems-redundancy - and the inefficiency of the policies-the structural bonds - enacts a symptom that proves that no "cure" is possible. Therefore, regardless external inputs and in the spaces left empty by instrumental gaps, the structural bonds support and enact themselves the redundancy of the territorial matrixes ${ }^{11}$. They don't work the impasse out, but contribute to establish the event in a sort of autopoiesis [16] [17].

\section{The Double Bond and the "Territories of Emergentism"}

\section{Aquila Frame: disqualification of communication}

The earthquake that hit l'Aquila and the Abruzzo region reached its peak on April 6th 2009 at 3:32 with a magnitude 5.8 Richter scale leaving behind 308 victims, over 1500 injured and billions euros in damages. After 5 years Aquila's earthquake hold on 3500 opened construction site, 8.5 billion $€$, 43,000 people came back their home. Beyond the tragedy, the case of l'Aquila showed how badly the emergency was managed by the national government and the international resonance the verdict by Italian judges against the official government body called the "National Commission for the Forecast and Prevention of Major Risks"12 had. The media operation around the earthquake played a key role, especially for the then Prime Minister Berlusconi and the project to develop 12 new towns post-earthquake reconstruction. The laughing of two entrepreneurs expecting business opportunities from the earthquake were caught on tape on that very night.

Expertise, as a guarantee of safety, was juridically and penally questioned for what concern the communication of such event.

"Why are you using such a reassuring language [...] when probabilistic statements would need a more cautious language, not so a bit less clear and therefore don't you think your are reassuring people when no reassuring conditions can't be given? [...] Motivations have ground on the 'extremely uncertain situation' [ibid: 130] in predicting the occurring of an earthquake. Anyway as to contain uncertainty and reassuring the populations there is no better political strategy than letting top experts speak on the subject so to ease the conflict. [...] Mr. Bertolaso confirmed he called for the need to 'make people feel still' and to engage a media operation. Bertolaso says: instead of me and you talking we get the top earthquake experts to speak [...] let then be known we're having this meeting about the media business" (Interrogation of Public Prosecutor Picuti to prof. F. Barbieri, l'Aquila Court: 122-123, 130, 131).

Looking carefully at the structural bonds through the frame of l'Aquila, the mechanism of the autopoiesis seems to feed itself and not to wear out when the tools mediation or the expertise are implemented. In the case of the frame of l'Aquila the experts' how-how comes out clearly as a strategy of communication and of biopolitical domain [18]; a strategy strengthened by the emotional shock the aftermath of the natural disaster had caused in the population.

This relationship has the characteristics of the double bond [19]: on their hand, the institutions have learnt how to exploit intentionally the event from a physical accident to an apparatus [18] [20] [21] ${ }^{13}$ to trigger the control over territories; on the other hand, the social systems unawares react to these solicitations meta-communicating the event itself and engaging stages of collective paranoia [10] [22] ${ }^{14}$.

\footnotetext{
${ }^{10}$ Until 2012 (footnote 12) this matter was regulated by the Law $n^{\circ}$ 401/2001 which join the competencies of Civil Protection: the so called "Big Events" - with the aftermaths of the state of emergency/exception-with the "custom" of decree power.

${ }^{11}$ That is the fragility and physical vulnerability.

${ }^{12}$ This Commission links the Dep. of National Civil Protection with the academic and scientific world. That's—at all-the assurance of highest national scientific authority in the field of risk prevention.

${ }^{13}$ The Apparatus-according to Foucault-has decisively a strategic nature [20].

${ }^{14}$ Very close to the Weick's concept of arousal [23]. Looking at social behaviours such as forms of "collective psychology" allows us to introduce the Watzlawick thought—-the pragmatic of communication — and the "double bind theory" [19] for which healing the symptom becomes in effect the bond to non-healing.
} 
Institutions and social body activate a communication which terms of exchange strenghten on a double channel; the exception and the emotion. Looking at social behaviours such as forms of "collective psychology" allows us to exploit the Watzlawick thought introducing the "double bond theory" [19] for which to care the symptom becomes indeed the bond of no-healing. So institutions and social regimes activate a communication which terms of exchange strengthen themselves on a double channel: exception and emotion.

\subsection{Exception: Institution $\rightarrow$ Use the Event $\rightarrow$ Affects the Social Body}

At first sight, public intervention appeals to the emergency in order either to settle crisis that are not predictable or to make up the mismatch between legislation and planning failing in engaging the causal bonds needed to trigger policy implementation ${ }^{15}[24]$.

The cyclical exploitation of the "urgency law-making"-as usual procedure-leads to extra-ordinem regimes as out-and-out real "states of exception" [15] that as a matter of fact subvert the ordinary management and twist entire sectors of the institutional planning. Valsusa, the G8 scandal of Maddalena, l'Aquila, the management of the health system in Calabria, Ilva, the trash issue in Napoli, "terra dei fuochi”, Muos in Sicily, all the management of the "Big Events"16 keep on adding on in the national agenda of socio-ecological conflicts, that doesn't include all of those that are "silent" but emerging in the long term [25].

In 13 years-from 1992 to 2005, 15 different types of commissioners were appointed to serve the increasing 10,000 external administrations all over Italy $^{17}$, they all go by the practice of puzzling and overlapping emergencies with strategy making (see Iva frame).

"[...] in the XVI legislature, from May 2008 to August 2010, in 63 gatherings of the council of ministers out of the 104 held were adopted 47 declarations of state of emergency, 107 prorogations of the state of emergency. All together, therefore 154 emergency measures in 104 gatherings of the council of ministers [...]"18.

The issue has been raised up several times by the "Corte dei Conti" 19 and-as the case of l'Aquila suggests - the proliferation of the so called "external administrations" hasn't generally led to the settlement of conflicts or problems they generated in the aftermath of an emergency. Actually, the states of exception highlight heavy negative externalities both direct-in terms of de-construction of the social, cultural, ecological capi$\mathrm{tal}^{20}$-and indirect imposed on the Public sphere when concerning planning, parasitism and opportunism. As a matter of fact, in the autopoiesis of the event we see the mushrooming of the processes of juridical imperativism for which the juridical reasons are independent from the content, from the interacting variables.

The commissioners - then - avail themselves of consultants, local groups that manage consistent fluxes of expenses, emoluments, mixed architecture companies directed awarded of contracts reporting abnormal expenditures. That enhances the cronyism ganglia, in addition possible margins of lawlessness ${ }^{21}$ and discredit of institutional authorities. The mechanism grows on itself [26] fed by cyclic liturgies of power. Derogations over

\footnotetext{
${ }^{15}$ The implementation research theory is huge: in general the approaches diverge from a "top-down" one-close to the Pressman and Wildavsky [24] argument—-to a "bottom-up” one (Barret, Fudge 1981; Bonomi, 2010).

${ }^{16}$ The normative background provides the proliferation of executive measures overwhelmed the prevention scenario: as explained by the Law L.9 November 2001 n 4011—enacting the "Big Events”-and the D.L. 23 May 2008 n 902 which removed the Civil Protection orders to the ex-ante supervision of legality by the "Corte dei Conti". The comma 5, art. 5-bis, of Law L.9 November 2001 n 401 : "The arrangement referring to the article 5 of the Law of 24 February 1992, n. 225 shall apply also referencing to the declaration of Big Events within the jurisdiction of the Department of Civil Protection and other than those for which it is necessary to the resolution of the state of emergency". ${ }^{17}$ At least 2 compulsory administration per day. Cfr Il sole 24 ore, 25 February 2005.

18“The Law n. 225/1992 established the "National Service of Civil Protection", otherwise by the Law n. 401/2001 the the procedures of emergency have been expanded beyond the natural calamities and disasters enacting the so called 'great events"”. cfr. "La Governance emergenziale, l’ultima faccia della partitocrazia". http://www.radicali.it/

19“Corte dei Conti” belong to the judiciary body and supervises the administration of the public administration in Italy, so as to prevent and avoid the bad management of Public funds. The promulgation of Law n. 27/2012 has radically reformed the proliferation of extraordinary measures determined by the Law n. 401/2001. The latter Law n. 401/2001—has established the so called "Big Event" and removed the National Civil Protection action to the ex-ante supervision of legality of "Corte dei Conti” (cfr. Resolution No. 6/2007/G, Resolution No. 5/2010/P). Several parliamentary commissions of inquiry were established since the 2006.

${ }^{20}$ For instance projects like the TAV Turin-Lyon are widely-scientifically recognized the not-relevance in terms of economic development for local communities in turn of significant socio-environment negative externalities and heavy social conflicts.

${ }^{21}$ Gribaudi [26] narrows the waste affair in Naples as an "emergency not-emergency" model: "[...] It has created a system in which every junction had inefficiencies and gaps, and in these inefficiencies the work of the Camorra infiltrated: transport contractors and garbage disposal had subcontracted to other companies, and themselves in turn subcontracted to other companies even smaller. This appears a chain without control in which easily enter local criminal organizations that effectively control the, territory and have the monopoly on the ground movement in the province of Naples and Caserta" [13].
} 
derogations ${ }^{22}$ are created and structured by the auctoritas - the Executive power which are delegated the ordinances of states of emergency-to produce supplements of potestas ${ }^{23}$, in which the state of emergency-exception becomes the rule [ibid: 110].

\subsection{Emotion $24:$ The Social Body $\rightarrow$ Use the Event $\rightarrow$ Exploits on Institution}

Where double bond arises, territories are unable to respond to the message the emergency they are living is addressing: "if you want to repair the damages the accident generated, you need to work under a different system of legality". Social systems are the bodies establishing the communicative channel that make the new conformative exceptional system accepted, as it is normally seen in cases of an event of collective paranoia [22] [27]. In the aftermath of an emergency, redundancy and bond interact in a closed system, reducing the channels of communication and the spaces for socio-organizational learning. Very few strong actors keep the power of the relationship and of the communication inducing the people involved in the event-weak and injured by the event, to the co-participation of the exception by way of an unconditional proxy in order to get the restoration of ante-event. For Sartre, the emotion is a way to learn about the world but within these frames, the maximisation of the emotional datum - the arousal [23] — negatively affects the standard fluxes of information and of social and organizational and transforming the sensemaking [ibid] difficult. The lack of sense produces an emotional selection of the information that is pathological and that includes the plausibility more than the accuracy of the relationships and where the collaborative role between institutions and communities disappear in favour of alienation. In fact, if public action spreads the exception on the territories in a way, that no longer communicates solidarity but repulsion from on the other hand the communities are not induced to give more morality than they have received in exchange [22].

The unconscious compensation of arousal and exception on one hand, temporary re-balances the distribution of territorial bads at least to the next event, on the other strengthens double collective messages with distort and passive effects working as a deterrent to substitute to the many exercises of public innovation, social creativity, of territorial experimentation.

This double conformity to the event defines the boundaries of "territories of emergentism" as a social construct where institutions and communities work in a hidden structural system [28] and closed one ${ }^{25}$ exploiting socio-ecological crisis. Within the national outlook, these relations take a huge space ${ }^{26}$ against a radical reduction of communication channels, useful to social-institutional learning processes on which to engage the ordinary implementation and define alternative political spaces [2] [29]-[31] ${ }^{27}$.

To the multiplication of emergentism as a strategy of the territorial policies, match a growing elusion towards renovation of political spaces in terms of capacitation of the territorial systems and of institution building. What comes out is rather a temporal paradox, with the pretext of acceleration of the procedures amplifying those temporal misfit of the efficiency of policies that make structural the waiting times towards the results, instead of multiplying the positions of benefits and of social parasitism. This temporal misfit is not a container of meanings, it doesn't enrich the territories of patterns of interaction but it is rather an empty time, which lack is reduced only with the opposing, resistant [32] insurgent [28] [33] [34] social action: in the space of the conflict.

\section{Alienation and Policies of Inversion versus Recognising Practices}

In order to break the double bond, the "Palo Alto school" suggest a paradox: the prescription of the symptom

${ }^{22}$ The extra-ordinem practices seem to have no end in Italian administrative praxis: exceptions were fed even further by new decrees, new emergency measures, extraordinary measures, injunctions for detailed procedures assigned to Special Commissioner. Exemplary is the waste affair in Napoli-described by the "Corte dei Conti" [35] in the resolution $n^{\circ} 6 / 2007 / G$ — that reveal the progressive interest—between public and private - in the managements of emergency. From 1997 to 20005 in 5 Region [Lazio, Sicily, Calabria, Campania, Puglia] the expenditures for extraordinary commissioner arose 1.8 billion $€$, which the $21 \%$ of them in salaries and administrative activities. Moreover the "big projects" have never implemented or poorly working, leaving opened building site during, extending the state of emergency.

${ }^{23}$ According to Agamben, [15] [18] the quality of the "Auctoritas" is linked to the bio-politics implications as anomic and meta-juridical settlements. Otherwise the "Potestas" is linked to the deontic and juridical settlements. The former can interrupt the latter.

${ }^{24}$ Arousal in Weick [23].

${ }^{25}$ In thermodynamics—-subsequently in social sciences and in social psychology—a "closed system" is a system that does not allow transfer of mass or information.

${ }^{26}$ According to Lefebvre [2] the space held a political role determining — through social interactions—a framework of social control and transmission of knowledge.

${ }^{27}$ That occurs independently by implementation research model: set on the linear cause-effect model, or the "perfect institutions" model — top-down [24]—, as well as those involving the active role of different actors interacting —according to the bottom-up approach (Burret, Fudge, 1981). 
[19], as the bond to be cured is a bond to not healing. Therefore, as to overcome territorial alienation of the policies it can be tried to prescribe the bond itself: the exceptional use of the territories engaging processes of exploration and exploitation [36] thanks to which the policies can acquire skills better belonging to the world of practices.

The engagement of the weak thoughts and bonds ${ }^{28}$ [36] changes the typologies of the conflict inherited by the maximalist antagonists' schemes of the last century. To emerge is today the minimalist-aggregative component that starts a new space for the right and constitution of a socio-ecological constitutionalism [37]. By a matter of fact —as the Arabic spring shows_-antagonists struggles, although makers of social meanings and social mixes for policy, hardly generate those interaction patterns for innovation and socio-institutional learning, as the thought and social action better work if they go on gradually not by big sudden changes, in the incrementalism [38].

Not that big plans are to be rejected, but too often, they have delegated the action of the policy to the linearity of deliberation between means and ends, setting up the implementing factors towards an utilitarism strongly based on the best tool to apply. On the national territory, therefore, mediation factors arouse-technological and bureaucratic - leading institutions to misunderstand the means with the ends [39] and becoming co-agents in the sharpening of a new misfit between the administrative and socio-ecological elements [4]-[6]. This is clear in the case of Ilva on Taranto, where to "The New Industrial Plan"29 are delegated functions that do not belong to it. If the plan can activate economic qualification processes, at the same time it does not guarantee joint effects between the citizens and the institutions, nonetheless can be of social and constitutional use to guarantee balance.

By the dynamics of autopoiesis stand out the alienation as a by-product [40] of the loss of sensemaking between institutions and social body with subjects unable to determine their actions. The consideration it generates about the policies is not regarding the loss of effectiveness of the roles of bodies traditionally community relevant - the Nation-State- but mostly regarding the new processes of identification and re-appropriation. When released from the Marxist theology, they become the chance to gradually reach learnings able to shape the relationship between social systems and institutions gained from the knowledge of experience and from the exploitation of social practices as renewed political spaces and of freedom.

The best results for territorial policies are those in which public action comes back to be collaborative and bring with the current processes of a new socio-ecological constitutionalism [37] made of federative thoughts and practices aiming to create new political and right spaces. The policy gaps are worked out in the pluralization of the social resources, in the ongoing re-formulation of the expertise knowledge as the only asset able to produce innovation. To be efficient, the Wildavsky chains of delegation-that filter learnings and favour implementations - should not erase themselves vertically in the state of emergency or turn down in the antagonist tactic, raising and standing, but evolving horizontally, thickening the channels of communication and encounters.

\section{Threshold, Deviant Studies, Territorial Marginality}

\section{How overcoming territorial alienation ${ }^{30}$ ?}

To expect that public action is what makes policies substantial is an ideological abstraction that leads to repressive consequences and can generate territorial alienation. Public action can bring with the policies helping the transition through processes of caring (à la Heidegger) and proximity [41]. When free from the mediation that tools generate, public action uses the waiting time as a chance to enact processes of learning and producing renewed space where expertise and practices patch together. Putting into practices processes of creative and transformative reconfiguration of the socio-institutional meanings so to mark it with an inedited style is a possibility to make society evolve towards and ethic of responsibilities and not of convictions ${ }^{31}$.

Three cases of securitarims use of territories are now introduced, highlighting a peculiar type of alienation that starts from micro-policies of some municipalities of the Venetian area, not far from Venice. How Roma and Sinti group have used the physical space is the territory of inquiry — maybe useful in the macro scale—in order to involve processes of (micro) social constitutionalism and of re-appropriation of rights. Through the care of

\footnotetext{
${ }^{28}$ Maybe against the recent Zizek's thought.

${ }^{29}$ Ongoing, the 2014.

${ }^{30}$ In Rousseau, Kierkegaard, Heidegger or Marx works, alienation has to replace a process of re-appropriation as an authenticity of the Subject to which returning. According to Foucault—who did not like the term alienation-is necessary free the repressive mechanisms of social control and dominating to bring out an authentic subjectivity.

${ }^{31}$ According to Max Weber distinction.
} 
processes — practices of taking care-[42] new policies experiences are introduced within an area of proximal development between societies and institutions, where interaction happens without roles, functions or tools mediating it [29] [31]. In this frame, alienation can be transformed into practices of re-appropriation and identification completely different one to the other (à la Jung).

\section{Alienation and Securitarism Meet the Autopoiesis}

The issue of "public security" comes out in the Municipality of Castelfranco Veneto ${ }^{32}$ : here, local institutions have always considered the "issue of nomads" in terms of cultural diversity, criminality and favouring actions that help to displace those who make such "problem".

\section{Storyline 1: the "Sinti of via ${ }^{33}$ Brenta"}

The tsigani group in hand is called by local authorities the "Sinti of via Brenta", almost if they didn't have a surname but were identified only by the local toponym. It's a frown-up family and suspicions of criminality allege upon them that—in the 90s — bought and settled in a piece of land in Via Brenta.

The area is "a former built site", between high circulation roads and a farming-residential area. Following internal arguments in 2007, the members of the clan decides to sell the land, left with no other place where to stand stably. They therefore contact the local authorities to ask for a lot where to live. The "demand" was rejected several times and was suggested to apply for social housing, following the standard ranking procedures. The Sinti refused the offer and periodically reiterated the request of a place where to stand and live. The Municipality - through the mediation of some informal social groups-agreed to lend them temporarily the van area near the parking lot of a supermarket. It's the very same administration, shortly after, to move them away due to the terrible conditions they area is kept after the "occupation" by the tsiganis. The families are once again placeless and the expenses to restore the place are on the public administration. The Sinti of Via Brenta decided then to depart Castelfranco and to move towards Trieste; but—as the Mayor of Castelfranco says—are then sent away and forced not to come back for three years due to-alleged—criminal activities. They come back to Castelfranco adopting a strategy of adaptive "peripateticità" [43]: a semi-nomadic itinerancy on pre-defined and never changing paths ${ }^{34}$.

Compulsory evictions by the local police are frequent; the actions are inducted by alarming phone calls of gagé citizens living in the nearby. The situation become almost routinely and grotesque, where a group of nomads illegally camps in a public parking lot, some citizens complain for the proximity and for the poor health conditions, the administration officially order the eviction and the police makes sure the Law is enforced. The people involved are therefore inducted to occupy another "public land" where everything soon will repeat itself as in a perpetual motion ${ }^{35}$.

Any interventions, however, needs at least, one opportunity. And the situation, as a matter of facts, erupted. Complaints become more and more frequent and some neighbourhoods start raising the issue of the "new neighbours" to their meetings, the press sporadically uses alarming titles in their articles, and the phone calls to the Municipality offices intensified. The local municipality that so far had managed the issue without proactive responses, but only by constantly denying the "itinerant" Sinti requests for an equipped area, is now legitimated to become a protagonist and to use the deontic tools it has.

The state of exception is created by denying water, electricity and gas supply and the possibility of a stable settlement; it justifies its intervention by recalling abstract principles of decorum, order and cleanliness. The chance is given by a National Law, the so called "safety decree"36 in order to send away permanently those unwelcomed and unusual guests. The solutions simply implies the expulsion of the group that "is the cause of the problem" out of the legal borders of Castelfranco delegating other solutions to other bodies. Many vans disappear from the usual parking lots as more and more copious no parking signs for auto van are placed.

The storyline highlights how difficult it is for institutions to face a problem that is social and therefore hardly "framable" within the norm system, nonetheless the need to put into safety such situations potentially generating

\footnotetext{
${ }^{32}$ Castelfranco is a Municipality of 30,000 inhabitants in the rich and industrious North-East of Italy but at the same time overwhelmed by the Lega Nord regionalism and by xenophobic impulses toward immigrants and nomads.

33“Via” is the Italian expression for street.

${ }^{34}$ They were forced to wander between the railway station car park, the supermarket and another not far shopping center.

${ }^{35}$ Evacuations are merely induced keeping the problem alive, denouncing rather the institutional incapacity or indecision in management the arising social conflict. However it opens a micro-mechanism of autopoiesis, which strengthen the negative externalities such as the legitimisation and enforcement of "ordinance tools".

${ }^{36}$ Law No. 94, 15th July 2009, dispositions in matter of public safety.
} 
conflicts and that question the authorities and skills of institutions. The problem best worked out by strongly hiding it at the expenses of a chance for ethnic-social interaction and inclusion. Not knowing which tools to use and fearing the disapproval of the electors a perfect apparatus is established (à la Foucault) that charges the weakest subjects with the entire responsibility. The municipal administration traps the Sinti group, again with the double bond strategy [19]: it forces them to never stopping moves and then labels them with nomadism and social specialism. That allows the intervention by way of lex specialis, engaged to work out what stands "outside the norm" and justify forced actions of exclusion and de-responsabilization. The Public acts by "setting aside", socially and humanly, providing negative solutions to conflicts that could lead to new forms of citizenships but that are hardly understandable through the pair de lunettes of the gagè. Such peripatetic groups [43] colonize marginal spaces by making them more personal: clothes lined on the sun, tables and chairs standing outside the trailers, music that plays along the day. They do not surrender but resist to the social exclusion, which they are inducted in by the social climax and that too often threatens them. The fear is double sided indeed. On one hand, ghettoisation makes them victims of curious and scared glances, on the other, they fear violent actions on them by some gagé: thefts worry the inhabitants, the empty bottles of beer scattered on the top of the trailers after football matches worry Sinti parents. If residual and marginality can be spaces of re-invention, they also could be places of potential and actual threat—as the case of the neighbourhood Tamburi in Taranto suggests.

\section{Alienation and Specializing Familism Meet the Collective Emotion}

Castelfranco has also been the place that showed that another way of living territorial marginality, when a different interaction between groups of tsiganii and gagé citizens occur is possible. That is the case of two tsigani families, the Stepich and Parussati, living in Castelfranco since the 70s. For them the common history and the efficient action of "bridging actors" [44] managed to build tsigani dialogic spaces and territories of social relevancy.

The Mayor herself, —in charge from 2000 to 2010_, during an interview shows some affection, as her job as an elementary teacher gave her the chance to know the children of Roma and Sinti families at school.

For Stepich and Parussati the institutional storylines are detailed in the everyday vicissitudes and more accommodating in the formal procedures activated; a very different approach compared to the previous one, banally named the Sinti of Via Brenta or Roma of Via della Grotta too often referred to as one would do if speaking about any criminal group, and for whom is usually triggered the appeal to emergency Laws.

The former Mayor speaks in more details about the Stepich family, who came to Castelfranco in the 60s and whose stories seem to be an integral part of the history of the town, now a small city ${ }^{37}$. Her talk is full with anecdotes and details about the habits of the Stepich family, talking about specific characters or particular episodes. The story is interwoven with several actors, single people or informal social groups that contributed to make bonds or were just part of single episodes, sporadically or continuously according to what they could offer in order to give to the families the best conditions of welcoming and integration. That's the beginning of the story, a situation where volunteering groups and citizenships are bond together.

\section{Storyline 2: Stepich and Parussati}

At the beginning of the 70s a Roma group moved from Padua to Castelfranco and they settled in an area near the football stadium. The head of the family is an old woman with many children. She then will be the person mediating between the Roma and local authorities or the informal social groups that will deal with issues and the problems concerning the group and the city. Following a first period of settlement in such low quality urban are, the family moved in a neighbourhood considered better for what regards life and house conditions. Neighbouring families soon started helping (with clothing, food, etc.) the new comers, moved by tenderness, especially towards the children and mostly for the immoral conditions they lived in. This is how the citizens first got in touch eth Roma. Also volunteering groups and informal groups of people contributed, especially the community of S. Vincenzo that promptly took responsibility over the unusual situation. The relationship is mostly based on giving-receiving. Also local authorities perceived the precarious conditions and therefore decided to give to those people a piece of land owned by the municipality where also an old farm house stood (called Casa Caon), on the border between a residential area and farm lands. In exchange it is asked and obtained a minimum

\footnotetext{
${ }^{37}$ The former Mayor tells about the great-grandmother Stefania, who arrived with a caravan forty years ago and has always been in charge of negotiations with public authorities. Moreover she tells about the third generation of Michele, Rosanna, and Gigliola who settled in Padua at the gypsy camp of Saint Lazzaro and finally about Carlo, Marcello and Nadia, who "have also tried to work" in the social cooperative Eureka for a short time.
} 
schooling for the children and improvements of health conditions. The agreement works: the kids are sent to school, the municipality built toilets and showers, the members of the family settled down. The interaction between Roma and citizens are ongoing: the Roma women often asked for door-to-door help and both price citizens and social service-especially Caritas (the charity orbiting around the church) and the social cooperative "Una Casa per l'Uomo-give what is needed. Also school authorities commit in looking after the kids

"it looked like they were living to different lives (says the mayor), recalling her experience as an elementary teacher, one tidy and clean and one with no rules. When they came to school they were clean, well dressed, tidy with all school material needed; while at home you could see them running barefoot, sweating, getting dirty in the mud".

The teachers agreed to take care of the children in their education, seeing them every time they were not at school and going to the camp site to keep an eye on their education, willingness and duty, yet moral ${ }^{38}$, went together with some sort of moral and cultural superiority that had roots in tidiness and hygiene The "men of the Stepich"-according to what the social workers of the Caritas say-seemed to be careless towards working duties. Although requests of material help came out from time to time (for furnishings, house bills, clothing, camp site facilities, school books and stationery). The Charity company asked then to the president of some social cooperatives working locally, to support a project to help the men finding and employment: the cooperative Aurora was founded to give work to Roma men and women aged between 18 and 40 helped by some volunteers to set up high precision mechanical parts. Nonetheless, after a first phase of enthusiasm and collaboration, problems regarding reliability and working times, and dutifulness arouse leaving the group with only few women, mainly employed in laundry, farms and assembling of industrial materials.

Citizens and the enlarged Roma family mutually identified themselves in the territory. Although some school difficulties, the poor commitment on the male side, the precarious situation of women, begging and petty crimes raise complaints, generally everything happens within a context of mutual respect of differences and awareness of living in the same urban space.

Also the toponym change: the nomadic settlement is now called Casa Stepich, named after the Roma family who lives there and that includes a big courtyard, a manor and some trailers. It's a private space known as an identifying symbol of a historicised tsigani group that found place in the collective imagination of the community of Castelfranco, placed in a residential area, handy for exchanges and interactions it both fulfils the living needs of the family without raising complaints.

From the usual policy spaces came out a territory of transition between authorities and the tsigani unusualness of: it is the space of informal social grouping, of bridging actors [44] but that are able to stay on the margins and work as "ferry men" for ideas and agreements. And, most of all, it is, on one hand, the administration is willing to make compromises and, on the other, the senior members of the Stepich family are not afraid to ask and trade favour or needs directly to the offices of the municipality. There, they find compliant politicians that accept to discuss issues on the ground of flexibility and mutual cohabitation.

The policies are wide minded in looking for different communicative and decisional channels, taking a loan from tsigani habits the weak languages [36] that are anyway able to solve conflicts. The different everydaymaker (à la Bang) is welcomed as pursuing the common interest of cohabitation and mutual respect, spontaneous participation stimulates the public administration to engage a "preferential way" for the Stepich members, aware they have been adopted by the community of Castelfranco. If social exchanges and interactions keep on intensifying, some sort of preferential and exceptional appointed can’t be denied to some Roma citizens that, unlike the Sinti of Via Brenta are acknowledged first of all as citizens of Castelfranco. It is a type of weak social inclusion that works with special groups and not protected by changes of the political Law system. There's no need to "regularize" some issues—as urban/healthy conformities regarding the farm areas—as it is the direct acquaintance, not mediated, but path dependant to ensure legitimacy to the relationships.

Besides being a "good" and exclusive relationships, even for what concerns the Stepich family a state of exception is engaged. Unlike the previous example, it protects and legitimates actions not always responding to the norm. If, on one hand, it evens the conflicts preferring informal agreements, on the other it is unable to guarantee long lasting forms of citizenship as strictly connected to the direct relationship with the Mayor and even less able to contaminate the other marginal situations in the territory. The institution acknowledges in the Stepich the participation of elected groups but refuses to acknowledge any other attempt to bring social innovation; it ex-

\footnotetext{
${ }^{38}$ Determined by a sort of Christian “charitatism”, strong rooted in North East of Italy.
} 
plores social tsigani territories only when they are part of the collective memory and therefore the collective emotion, but is reluctant to be contaminated with what is different if not expected. Belonging to the collective memory guarantees mutual reliability and the political expendability of the relationship, but it reproduces the communicative dynamics of emergentism in a sort of specializing familism. At the moment, no other communicative and relational forms able to explore the border spaces between institutions and diversity are identified.

\section{An Alternative: Asymmetry and Caring as Practices Opportunities for Territorial Policy}

\section{Storyline 3: Paderno del Grappa, towards the "Territories of caring”}

Paderno del Grappa is a small municipality inhabited by few thousand people in the venetian pediment area in the district of Treviso. The local history has interplayed with the history of a Sinti family about thirty years ago. Rodolfo and Margerita Reikard belong to the Sinti Teich group and travelling between Trentino, Lombardia and Veneto, where in 1998 they decide to buy and live in a municipal land of 2500 square metres and living by collecting and disposing of iron.

The first "landing" of Rodolfo and Margherita is the municipality of Fonte, adjoining to Paderno; public-private negotiating agreements led the Reikard family to buy a land used as farm land where to settle their trailers. "It's difficult to remain nomadic in a territory that pushes you toward sedentary". The camp is set up within the administrative city limits between the towns of Fonte and Paderno, in an isolated place and far from the residential areas, but mostly under the jurisdiction of Paderno. The administration of Fonte knowingly bounces the problem in the adjoining Paderno (like happened in storyline 1) that therefore has to find ways to govern a new situation of social instability. The land inhabited by the Sinti is "far from the eyes" and the Sinti themselves are happy not to be integrated and not to have exchanges that could lead to misunderstandings and not wanted influences ${ }^{39}$. "Not raising problems" to "well govern" is the guideline of local politicians that equip the camp site with toilets facilities in order to let the Sinti live decently, to be independent and to keep them far from the city life. Following such guide lines, the municipality purchases a 2500 square metre of adjoining land, next to the one already occupied, planning to build a "small town" with meeting rooms, medical rooms, toilets facilities and everything needed to a self-sufficient life not only for the Reikard family but for all of those passing nomads willing to stop. The too ambitious project needs consistent public investment is disproportionate to the real need and social scale of the problem and will never become true. In the meantime, the Reikard family feels the need of radically "appropriating" the occupied place and of giving new housing arrangements to a way of living that changed from nomadic and dynamic to a stable and "anchored" one. They therefore pursue small practices of colonization of the territory and — unaware and careless about the Law in force-builds a small house for the then old Rodolfo and Margherita. Neighbours' complaints follow and the municipality led by the mayor Bertoni turns the lot from farming to "service" area. Social legitimacy is, in this particular case, framed in the normative legality, crossing between legislative "correctness" and illegal urbanism, but that is guaranteed by way of everyday use. The buildings in the area are not strictly compliant to the Laws, but neither are unlawful. The issue will come to an end few years later when, upon the death of Rodolfo and Margherita, the house will be burnt down as the cultural rites prescribe ${ }^{40}$.

The situation is border-line, the Reikard case is filed by the Municipality that, during the 90s is able to catch the public opportunities that allow the sedentarization of a group historically known as nomadic and moving. Those are the years when funds are allocated by the administration—exploiting the Regional Law n. 54/1989 - to supply the camp site with toilettes in order to guarantee minimum standards of hygiene for a decent life. This is one of the reasons that will push the Mayor Ceccon—elected in 1999-to manage the local tsigani context to set it free from welfare dependency and making it self-sufficient. Umberto Ceccon-Mayor of Paderno from 1999 to 2009-understood how useful it would have been to take actions to guarantee to the people in hand a way of living the territory socially accepted and decent. What followed is a time of intense acquaintance and collaboration to improve both healthy and social conditions and school—working situations of the people inhabiting the camp site. The works are planned not only for the Reikards but also for all of those passing Sinti or Roma groups as to guarantee that their temporary stays happen an a healthy environment, avoiding the com-

\footnotetext{
${ }^{39}$ During these years, the centre-right government tries to find housing and healthy solutions exploiting as more as possible the regional Law 54/89 "Measures to protect the culture of the Roma and Sinti".

${ }^{40}$ They recovers materials of different types (from wood found nearby to pieces of wall from the houses destroyed by the earthquake in Friuli in 1976) and they build up a first home- “obviously abusive”.
} 
plaints of the local communities. The Reikards perceived such decision as a privatisation of the area in their favour, the sinti became a bit gage. They are suspicious, unwelcoming and reject unknown groups, seen as a potential thread for the property, nonetheless to the reputation of the family should they engage illegal activities or not proper behaviours. The mayor visits the camp site about once a month to listen to the requests of the family, to monitor the "smoothness" of life in the camp site. Ordinary maintenance services such as toilets and roads are time by time brought up with determination and the most find accomplishment. The everyday life of the small town plays a key role, turning the institutional relations into mixed relationships, that when supported by a favourable Law system, help both mutual understanding and speeding up of interventions. Several of the requests put forward by the inhabitants of the camp site are accomplished on a voluntary basis and by word of mouth and it's difficult to trace all the actions undertaken and the interventions made. Requests for ordinary maintenance, such as roads and toilettes, time by time are brought up with determination but are mostly accomplished. The everyday life of the small town plays a key role in turning the institutional relations into mixed relationships, that when supported by a favourable Law system, help both mutual understanding and speeding up of interventions. Several of the needs brought up by the inhabitants of the camp site are accomplished on voluntary base and by word of mouth and it becomes difficult to trace the different actions and the many interventions. "There's a mutual acquaintance that in some ways gets things working" and that activates networks and projects that involve the Reikards. In some way, it's the Mayor himself, by visiting the camp site that blends and hybrids the borders between institutions and direct acquaintance ${ }^{41}$.

During the 90s the Veneto Region legislated a lot regarding the subject of Sinti and Roma, playing broad attention to the interwoven subjects of residency, suitable areas to camp, health conditions, compulsory schooling for the underage and opportunities of employment. The Administration of Paderno attempted to provided solutions involving both the local politicians and the social services ${ }^{42}$. The attempts do not rely on an authoritative decision making but the building up of trusting relationships between the populations and the social workers. Well-structured projects to support schooling for children—such as InSINtonia ${ }^{43}$ —based on a system of interactions not balanced but dynamic are activated.

The goal is more ambitious in terms of facts and aims to "lift" the Reikards from a situation of welfare support and less dependent form exception, but able at the same time to use the series that institutions can provide. As a matter of fact, the reasons the Reikards visits the Municipality offices for change in time: the informative and educational "training" the social workers carried out, helped the family to learn that they can have school expenses refunded provided they have a receipt for the school material already bought. In this sense they face the very same problems local gagé families ${ }^{44}$.

Social workers act as bridges between the exception of the sinti and the arousal of the gagé. They work as some sort of "maternal figures", active in the camp site, designed to succeed where misunderstanding and mutual prejudice-between the Municipality and the Reikards—still opposed resistance to confrontation and collaboration. The small arena engaged is committed to periodic meetings in order to understand and know the Sinti culture, to lean ways of interaction; to test and confront about the progress of the projects and the roles played.

Therefore, this is not the case of a unidirectional education, adaptation and integration on one side towards the other but a mutual adjustment based on knowing each other and respect of what is considered different. When grandpa Reikard waits his grandchildren outside school for four hours in a row—worried about what might be happening inside—-he's not a strange and suspicious man, so the school teacher that "steal" the sinti children for an entire morning keeping parents from seeing them have no intention to kidnap or mistreat them. Aiming to understand that prejudice is on both sides, the promoters of the project "InSINTonia" try to open doors, to change the message to get to different social groups with equal rights to live together. The difference is visible

\footnotetext{
${ }^{41}$ The settlement of the area is normative border-line, so the Mayor wants to know which are the difficulties or needs and at the same time have a confidential speech with Alberto and Imperia.

${ }^{42} \mathrm{An}$ area of 5000 square meters was equipped with two toilet blocks, three little wooden houses anchored to the ground, seven caravan and a garage. Started many projects aimed to children finalised to a continuos educational path that leads into professional occupation. The seven sons of Alberto and the four of Ester are followed through the project "In SINTonia", but also through a strong partnership between schools and Social services. This actors work together to ensure regular school attendance to the children.

${ }^{43}$ The "In Sintonia towards the educational dispersion" project started during the years 2003-2004 and it take into force due to the Regional Law n. 54/89 and to the National Law n. 285/97 “Disposizioni per la promozione di diritti e di opportunità per l'infanzia e l'adolescenza”. The references have been Social Sanitary Services, Paderno Municipality, Territorial Centre for Social Integration, Veneto Region, Opera Nomadi and Cooperative Sestante.

${ }^{44}$ Do not ask money for transporting children to school by car, but instead has learned to take advantage of the local bus, to which may thereafter request the reimbursement provided for by National Law n. 62/2000 and n. 448/1998, or from the Regional funds.
} 
mostly when it comes to private citizens. When, at the beginning, whether it was lice infesting the school or little thefts happening or other similar problems arising, it was always them to be blamed, but in time, with daily proximity and the support of carers-teachers or social workers (Storyline 2)-mutual trust strengthened. The Project-designed to guarantee schooling to tsigani underage—-slowly spread to other ambits: first came acceptance and welcoming by the people of Paderno towards the sedentary nomads and the access for the Reikards to the possibilities provided by the social and public services including a deeper knowledge of the local institutions and of a new culture in Paderno-although well rooted in the territory and therefore important to govern it. Messages that became important when socially diffused as, in a small village, are daily encounters and favours that are worth. Tiny little actions, mostly invisible to all of those who don't belong to the community-meant in the broader sense- that actually proved themselves to be well established precisely because visible only within the actors involved. Voluntary practices, driven by common sense or the casual synchrony in the same space able to exploit the chances given by the moment: a quick coffee in a bar, a dismissed kitchen but still working, Andrea Reikard and another kid playing together. But also small local "mobs", where it is more difficult to deny a favour than to give it, where it is well known who is best to ask to get something in a quicker way.

\section{Conclusions: Territories of Caring: Identification and Re-Appropriation}

In Paderno gagé and tsiganii flexibly adapt and avoid being held up in exceptional or emotionally significant situations. When faced with the purchasing of a piece of land to let the sinti family settle within the administrative city limits, the authorities in charge response is to work on the situation folding [45], catching the legislative opportunities looming and weaving exchange and confrontation relationships.

Administrations not only commit to create social and everyday conditions respectful of human dignity and adherent to the best use of the Laws in force ${ }^{45}$, but also work to favour a path of identification and re-appropriation of the Reikard family.

- School and working projects leading to a gradual economic independency are favoured;

- "a nomadic camp", equipped with whatever is needed to everyday life is attempted;

- Traditional roles are de-constructed in the interaction. For instance, the Mayor becomes the role of informer and of bridging actor by visiting the camp every month, listening to the requests, accomplishing what is asked and by relying on a specific office (Social Services) to deal with the care of the relationship and the "educational path".

The Mayor-in particular-is the generating tile of a relationship that never becomes static and symmetric, but keeps on being dynamic to the "common ground" between Roma and gagé. He is the one who puts into place dialogic actions that are also continuing and thick, never shrinking the channels of learning, but indeed narrowing them and finding new ones. The fertile ground that paves the way to reciprocity [46] is achieved thanks to his personal actions: visiting the camp every month, listening, accomplishing, asking, discussing and using, at the same time, the legislative tools available.

Compared to the "Special Commissioner of the Government" in the several cases of national conflicts, the Mayor does not appeal to the lex specialis, but acts within the institutions, using them with intelligence and re-tuning the means on the ends. The role he exercises is not required institutionally, he breaks with the organizational inflexibility by seeking an alternative way, to overcome the problems and able to establish trusting and inclusive relationships where approval is not required in order to understand each other. Usual and preconceived roles need to be temporarily abandoned, favouring an everyday and informal habitus, avoiding anyway abandoning completely the personal institutional strictness and the authorities it carries.

If both sides of the relationship are able to open to new views, inedited ways to produce unexpected public goods are engaged, among which are trust, exchanges of points of views, the setting up of spaces for discussion, the abiding of norms and the personalisation of anonymous territories. What comes out can't be defined a successful arena in the setting up equal opportunities and mutual cultural consideration, but it can be said that the alternation of differentiated modalities together with the ability to reflect on the actors involved and supported by some sort of "common sense given in to cohabitation", have been good ingredients to create a common ground, not constraint with the emergency.

Alienation is carried out in the arena engaged, showing identification skills by using:

- Reflexivity, as a strategy of thought during the action, unlike the strategy of securitarism and familism of the

\footnotetext{
${ }^{45}$ Not the securitarism one of the Storyline 1.
} 
previous storylines;

- The ability of social re-appropriation through;

- Receptivity meant as will to listen and to develop new ways of telling stories;

- Responsiveness to the problem and learnt along the relationship: sympathy, cognitive and emotional disposability, acumen, perspicacity and commitment are not pre-conditions but conditions coming from the joint learning.

This double conformity is defined by Luigina Mortari the practice of having care [42], underlying the plural political, social, ethical, juridical valence and that-in the economy of this work-is the strategy to break the autopoiesis chain of the alienation of territories. It is not, in fact, as one might suppose, a way of relating that specifically involves the personal sphere of relationships, but a complex practice involving all of those situations where the well-being of the "Other" is the centre, not only the efficiency and effectiveness of the policies.

Institutional learning: identification

The tsigani territories often perceived by the gagé citizens as absolute alterity stretch a fan of inedited experiments to face the challenges that the many emergencies impose. In the small contexts where people meet and know directly, relationships are advantaged straight away, although it's true that, in the small arena of Paderno the "actors" of both sides have been able both to leave their pre-defined roles, identity themselves and rebuild themselves in new practices of relations that are context and inclusive. It's important then, "to be there in many" (à la Heidegger) according to a discretionally context that search wellness rather to an uncritical adherence to principles, codes and norms.

Tenderness, hope and compassion-apparently weak feelings and normally encircled within the personal sphere-are revalued as "intelligence of policies" as a "principle of identification" (à la Jung) able to see in depth, give dynamics and fully feel the reality of the Other and are actually very far from the twisted use communication has made of them as seen in l'Aquila. Weak feelings and the asymmetry of exchange [46] favour spontaneous forms of participation and attempts, often successful, of democratic cohabitation. The goal is not to overwhelm or disguise the norm, but being aware, that plurality gives more chances of finding a common ground and, in some cases to innovate.

The suggestion is not to "formalize" such feelings, but rather to point the possibility of a further move of acting towards ways that could approach the experimentation of territorial justice as tension towards the well-being of the Other. "Practices of taking care" is also the ability to not resort to welfare dependency that feed situations of static subordination and the inhibition of self-sufficiency and personal resources.

The everyday relationship that the Mayor and Reikard share is not like the one between the "the Special Commisioner and people of Taranto" or the one between the "the Commission Great Risks and people of l'Aquila". The phenomenon "meeting" end inevitably to change both the institutions involved and the sinti as well, forming them different in the relationship and changing them once the initial distrust has been overcome. In promoting the well-being of the Reikard family, social workers and Mayor put at stake cognitive, emotional, material, social and political capabilities (ibidem) that not only are able to overcome the technical and deontic specialism but that indeed turn the Law from an obstacle-as other examples and scales suggest-into an opportunity. If the "interaction is effective only when some individuals independently establish social relationships of reciprocity" ([47] p. 142) the practices of taking care are a declension of the intelligent action carried out by the institutions, with the former able to learn from the context they gave themselves up to and are real part of [31].

Learning, in Paderno is a "nonlinear path of the kind stimulus-response, but a process of mutual adaptation and coevolution" ([48] pp. 270-271) that can develop from multiple actions and patterns of interaction between actors and resources, never predetermined but in constant asymmetry. Assuming that it can be clearly noticed how in Paderno this happens only in detailed cases or situations already familiar with the effort and the sociopolitical action; on the other hand, when the issue is accustomed with individualism similar results can be achieved only when some actors, such as Social Services, "Opera Nomadi”, the schools enforce their actions. All the moments of interaction-in different matching-between institutional actors, sinti citizens and fellow gagé have led to a plurality of territories variously established in the everyday interaction of common uses ${ }^{46}$. The territory of Paderno - following the active and lively presence of the Reikard and the immediate responses

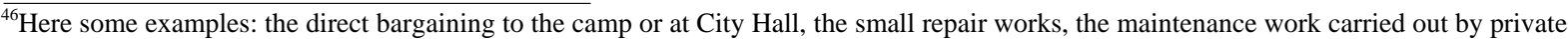
citizenship or by public operators, the food supplies by the religious institute, the private lessons to the children, the "In-SINTonia” project, the advice of Social Services, the attendance of spaces before feared by Reikard.
} 
and practices of the gagé-has multiplied its spaces and given itself new meanings, highlighting it dependency to the practices of use as a marker of socio-institutional possibility.

Re-appropriation of a political space between the "rule" and "life" to get free from the autopoiesis

The autopoiesis - that produces territorial alienation — swells in the wait and it's fed by the gap in the tools as seen both in the large socio-ecological conflicts (but also in Storyline 1). The use of care supposes instead the passage from a conflictual and accusatorial urge between actors and frame, to the sharing of problems as a practical and immediate ${ }^{47}$ junction of receptivity and responsiveness. Such practice of proximity is far from the social engineering (more employment $=$ well-being + democracy) able instead to put into play inverse forms of freedom, of determination, not of wait.

Paderno is, in fact, a trace (à la Didi Huberman)—a practice of experience-and an evolution of renewed political spaces to break the cycle generated by the autopoiesis and give a new frame of reference where the conflict between the norm and the life could find communication through the political actions. According to the securitarian or emergential models the lex specialis (the norm) is an exception to the legal system in force and is enforced prejudicially to everyday life as "biopolitical apparatus" as l'Aquila's or Taranto's people denounce. At the same time, as happens in the "familism" case, territorial activation (the life) strengthens a different specials norm, able to lead to a pragmatic government, but dependent of excessive state aid. In Paderno, instead, an innovative form of communication arouse, where the norms and territorial dynamics seek and uphold one the other, reducing the space in between. In the contingency, the norm acts simultaneously as amplifier of possibilities - allowing projects to be realized and interventions to be made-and as a circumscription for the possibilities themselves - through the rules the norm prescribes—allowing them to exist formally and to develop actions improving their life ${ }^{48}$.

In order to allow the bridging actors and the boundary institutions [44] to use such space in the correct way the connection between adherence in Law making and citizens' wants needs to be constantly kept on. The actors - that embody the role of informers or trickster (à la Jung)—are the key to free policies from mediations that are merely deontic and based on the tools. Bridges, informers, and tricksters (the Mayor, the Cooperative Companies, and the Social Services) engage experiences to a cooperative use of the territories, reducing the frames for conflicts and joining hands with the problem in a path of liminal search. "Staying and walking together" in the camp site as through local institutions becomes an explorative and questioning learning practice for the parties involved in the conflict and a possibility to re-map territorial alienation. Those same practices enlarge the borders of the emergency, from problem to opportunity, they don't re-balance the conflicts but are able to reduce, through the interaction of expertise, the gaps in modern policies. By de-structuring the arousal datum from collective occurrence to emotional intelligence, such actors show abilities in establishing social relationships based on communication through a syntax of affections and relations of proximity.

In such frame the Mayor of the small Municipality lays the subject in a relationship that is emotionally positive, not catastrophic where information is not restricted and simplified in order to make implementation smoother, but in which the communication — and behavioural—channels determinate the success of the policies. It's not a replacement but complementary with other learning forms that Public policies could approach diversity, emergencies and conflicts with, releasing the only solution it's been able to offer so far: the junction between legitimacy and legitimisation (auctoritas and potestas), the political use of emergentism, the product of the autopoiesis and the by-product of alienation.

\section{References}

[1] Crosta, P.L. (2010) Pratiche. Il territorio “è l'uso che se ne fa”. Franco Angeli, Milano.

[2] Lefebvre, H. (1991) The Production of Space. Bleckwell, Oxford.

[3] Hajer, M. (1995) The Politics of Environmental Discourse: Ecological Modernization and the Policy Process. Clarendon Press, Oxford.

[4] Young, O.R., Schroeder, H. and King, L.A., Eds. (2002) Institutions and Environmental Change: Principal Findings,

\footnotetext{
${ }^{47}$ Not mediate.

${ }^{48}$ The two spheres—one real and connected to the "life" and a more abstract one connected to the norm—take back again a common space where the interactions and dialogues that happen are no longer anomic. The policy is therefore a by-product of the positive and supported interaction and no longer the body that decides whether to enforce the Law violently-as the securitarism and emergentism examples showed—or—negotiate it—as in the cases of familism or arousal. Also in Paderno the emergency has opened a space in between the norm and the life-space of anomy_-but the interaction has here found out in care the mutual benefit to reject the "fictio iuris" [18].
} 
Applications, and Research Frontiers. The MIT Press, Cambridge.

[5] Folke, C. (2006) Resilience: The Emergence of a Perspective for Social-Ecological System Analyses. Global Environmental Change, 16, 253-267. http://dx.doi.org/10.1016/j.gloenvcha.2006.04.002

[6] Folke, C., Hahn, T., Olsson, P. and Norberg, J. (2005) Adaptive Governance of Social-Ecological Systems. Annual Review of Environment and Resources, 30, 441-473. http://dx.doi.org/10.1146/annurev.energy.30.050504.144511

[7] Galaz, V., Olsson, P., Hahn, T. and Svedin, U. (2002) The Problem of Fit among Biophysical Systems, Environmental and Resource Regimes, and Broader Governance Systems Insights and Emerging Challenges. In: Young, O.R., Schroeder, H. and King, L.A., Eds., Institutions and Environmental Change Principal Findings, Applications, and Research Frontiers, The MIT Press, Cambridge, 147-186.

[8] Cowles, M.G., Caporaso, J. and Risse, T. (2001) Transforming Europe: Europeanization and Domestic Change. Cornell University Press, Ithaca.

[9] Tedesco, C. (2005) Una politica europea per la città? L'implementazione di urban a Bari, Bristol, Londra e Roma. Franco Angeli, Milano.

[10] Radaelli, C. (2003) The Europeanization of Public Policy. In: Featherstone, K. and Radaelli, C., Eds., The Politics of Europeanization, Oxford University Press, Oxford, 27-56.

[11] IPCC (2013) Climate Change 2013: The Physical Science Basis. In: Stocker, T.F., Qin, D., Plattner, G.K., Tignor, M., Allen, S.K., Boschung, J., Nauels, A., Xia, Y., Bex, V. and Midgley, P.M., Eds., Contribution of Working Group I to the Fifth Assessment Report of the Intergovernmental Panel on Climate Change, Cambridge University Press, Cambridge, 1535.

[12] Grassi, T. (2013) Taranto. Oltre la notte. Progedit, Bari.

[13] Legambiente (2014) Ilva, Legambiente presenta settanta osservazioni al Piano degli Esperti. http://www.ecodallecitta.it/download.php?s=notizie\&e=pdf\&f=3344

[14] Douglas, M. and Wildavsky, A. (1982) Risk and Culture. University Press, Berkley.

[15] Agamben, G. (2011) Altissima povertà. Regole monastiche e forme di vita. Neri Pozza Editore, Vicenza.

[16] Luhmann, N. (1996) Sociologia del rischio. Bruno Mondadori Editori, Milano.

[17] Maturana, H.R. and Varela, F.J. (1980) Autopoiesis and Cognition: The Realization of the Living. Dordrecht, Holland, Boston.

[18] Agamben, G. (2003) Stato d'eccezione. Bollati Boringhieri, Torino.

[19] Watzlawick, P., Helmick Beavin, J. and Jackson, D. (1967) Pragmatics of Human Communication: A Study of Interactional Patterns, Pathologies, and Paradoxes. Norton, New York.

[20] Foucault, M. (1976) La Volonté de savoir. Gallimard, Paris.

[21] Deleuze, G. (1992) What Is a Dispositif? In: Armstrong, T.J., Ed., Michel Foucault Philosopher, Harvester Wheatsheaf, Hemel Hempstead, 159-168.

[22] Zoja, L. (2013) Utopie minimaliste. Un mondo più umano senza eroi. Chiarelettere, Milano.

[23] Weick, K.E. (1995) Senso e significato dell’organizzazione. Raffaello Cortina, Milano.

[24] Pressman, J. and Wildavsky, A. (1984) Implementation. University of California Press, Berkeley.

[25] Nixon, R. (2011) Slow Violence and the Environmentalism of the Poor. Harvard University Press, Cambridge.

[26] Gribaudi, G. (2008) Il ciclo vizioso dei rifiuti campani. Il Mulino n. 1, 17-33.

[27] Zoja, L. (2009) La morte del prossimo. Einaudi, Torino.

[28] Newman, S. (2011) Postanarchism and Space: Revolutionary Fantasies and Autonomous Zones. Planning Theory, 10, 344-365. http://dx.doi.org/10.1177/1473095211413753

[29] Crosta, P.L. (2003) Reti trans locali. Le pratiche d'uso nel territorio come politiche e come politica. Foedus n. 7.

[30] Crosta, P.L. (1998) Politiche. Quale conoscenza per l'azione territoriale. Franco Angeli, Milano.

[31] Donolo, C. (1997) L’intelligenza delle istituzioni. Feltrinelli, Milano.

[32] Mouffe, C. and Laclau, E. (1985) Hegemony and Socialist Strategy: Towards a Radical Democratic Politics. Verso, London, New York.

[33] Balibar, E. (2012) Cittadinanza. Bollati Boringhieri, Torino.

[34] Sandercock, L. (1998) Towards Cosmopolis: Planning for Multicultural Cities. John Wiley, London.

[35] Corte dei Conti (2008) La gestione dell'emergenza rifiuti effettuata dai Commissari straordinari del Governo. Relazione alla delibera $n^{\circ} 6 / 2007 / G$. 
[36] Lanzara, G.F. (1993) Capacità negativa. Il Mulino, Bologna.

[37] Teubner, G. (2012) Nuovi conflitti costituzionali. Norme fondamentali dei regimi transnazionali. Bruno Mondadori Editore.

[38] Lindblom, C. (1990) Inquiry and Change. Yale University Press, New Haven, London.

[39] Sini, C. (2011) Del viver bene. Jaca Book, Milano.

[40] Elster, J. (1979) Ulysses and the Sirens: Studies in Rationality and Irrationality. Cambridge University Press, New York.

[41] Bianchi, E. and Cacciari, M. (2011) I comandamenti. Ama il prossimo tuo. Il Mulino, Bologna.

[42] Mortari, L. (2006) La pratica dell'aver cura. Mondadori, Milano.

[43] Vitale, T. (2008) Politiche locali per i rom e i sinti, fra dinamiche di consenso e effettività eugenetica. In: Amendola, A., Bazzicalupo, L., Chicchi, F. and Tucci, A., Eds., Biopolitica, bioeconomia e processi di soggettivazione, Quodlibet, Macerata-Roma.

[44] Putnam, R.D. (2002) Democracies in Flux: The Evolution of Social Capital in Contemporary Society. Oxford University Press, Oxford. http://dx.doi.org/10.1093/0195150899.001.0001

[45] Jullien, F. (1997) Traité de l’efficacité. Grasset, Paris.

[46] Bruni, L. (2010) L'ethos del mercato. Un'introduzione ai fondamenti antropologici e relazionali dell'economia. Bruno Mondadori, Milano.

[47] Crosta, P.L. (2009) Casi di politiche urbane. La pratica delle pratiche d'uso del territorio. Franco Angeli, Milano.

[48] Regonini, G. (2001) Capire le politiche pubbliche. Il Mulino, Bologna. 
Scientific Research Publishing (SCIRP) is one of the largest Open Access journal publishers. It is currently publishing more than 200 open access, online, peer-reviewed journals covering a wide range of academic disciplines. SCIRP serves the worldwide academic communities and contributes to the progress and application of science with its publication.

Other selected journals from SCIRP are listed as below. Submit your manuscript to us via either submit@scirp.org or Online Submission Portal.
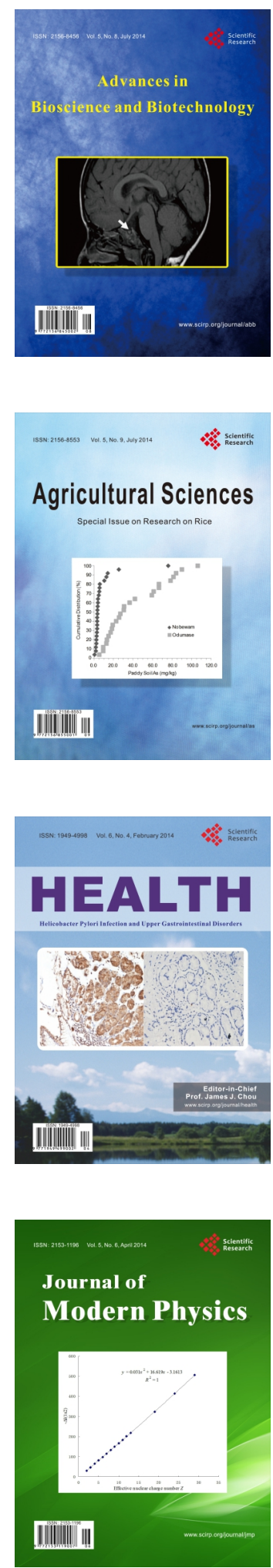
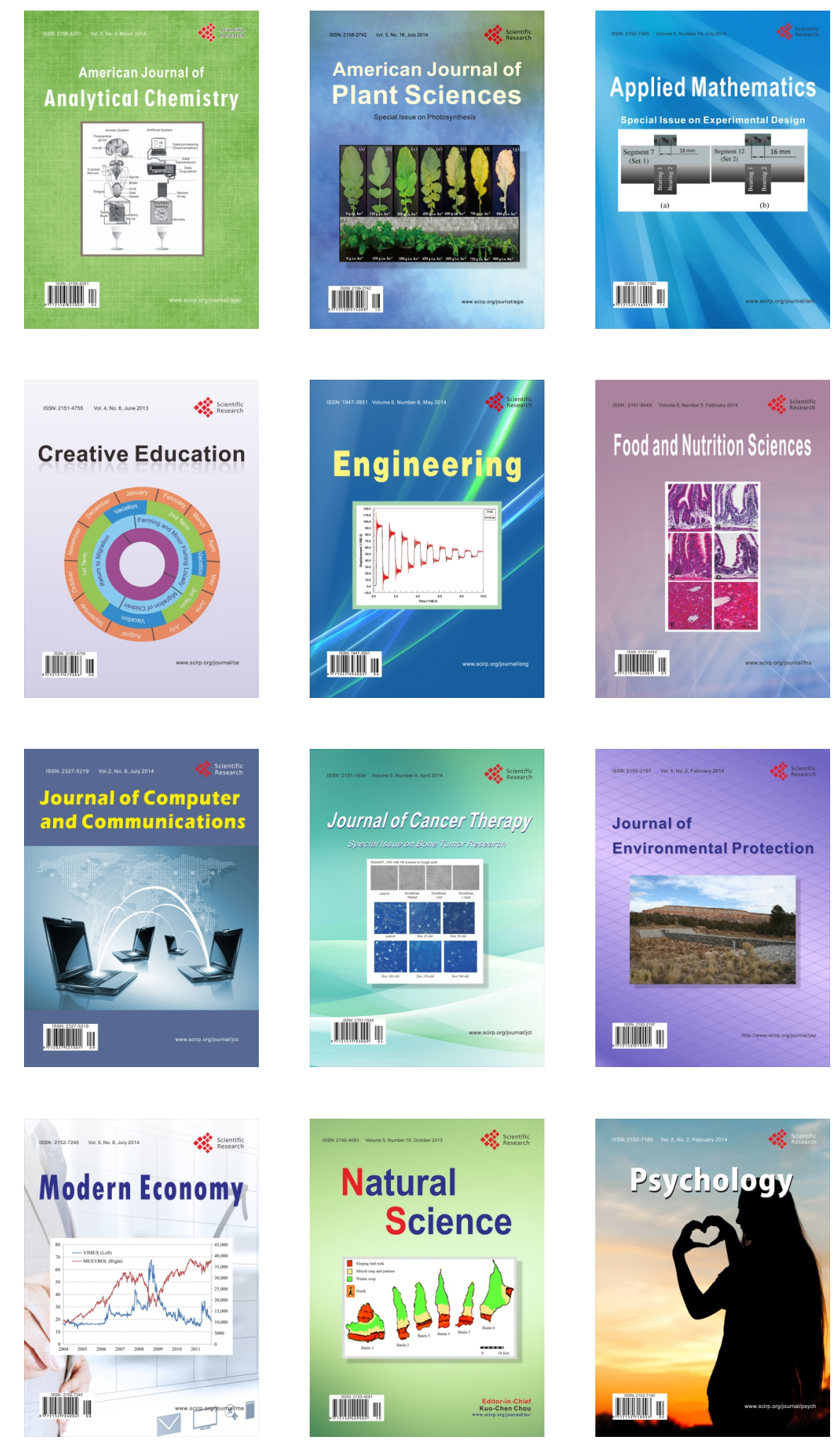